\title{
"IRMÃOS E COMPANHEIROS": A CAMPANHA DOS CANDIDATOS DA IGREJA UNIVERSAL NAS ELEIÇÕES 2004 EM PORTO ALEGRE
}

\author{
Marcio Martins dos Santos ${ }^{1}$ \\ Graziele Ramos Schweig ${ }^{2}$
}

Resumo: Neste artigo apresentamos os resultadosde uma etnografiadas campanhas à reeleição de dois vereadores do município de Porto Alegre (RS) que são também pastores da Igreja Universal do Reino de Deus (IURD). A partir do acompanhamen to de eventos diversos, tais como cultos, caminhadas e "bandeiraços", da coleta de materiais impressos e da observação das apariçôes dos candidatos no horário eleitoral gratuito, intentamos contribuir para a reflexão acerca das relações entre religião e política na sociedade brasileira. Sugerimos que houve um refinamento das estratégias eleitorais desta denominação religiosa: além da divisão dos bairros da cidade entre os dois políticos, que já havia ocorrido em 2000, neste pleito verificamos também uma distinção clara entre as campanhas "dentro" e "fora" da igreja, explicitada através do emprego de discursos bastante diferenciados conforme o contexto. Por outro lado, a análise da votação obtida pelos pastores-vereadores revela que, ao invés de uma ampliação, houve um pequeno declínio em relação ao pleito anterior, convidando-nos a uma reflexão sobre os limites da expansão eleitoral dos "políticos religiosos".

Palavras-chave: evangélicos, política, Igreja Universal do Reino de Deus, Porto Alegre

Keywords: evangelicals, politics, Universal Church of the Kingdom of God, Porto Alegre

O presente artigo aborda a campanha à reeleição de dois vereadores que integram a Câmara Municipal de Porto Alegre (CMPA) e são pastores

\footnotetext{
${ }^{1}$ Mestrando em Antropologia Social, PPGAS/UFRGS. Bolsista CNPq.
}

${ }^{2}$ Aluna do curso de Ciências Sociais, UFRGS. Bolsista CNPq. 
da Igreja Universal do Reino de Deus (IURD). A partir de um acompanhamento etnográfico de diversas atividades das quais estes agentes participaram ao longo do período em questão, bem como da análise do material impresso distribuído e de suas aparições no horário eleitoral gratuito, pretendemos realizar algumas reflexões sobre as combinações, imbricações e interações entre o religioso e o político na capital do Rio Grande do Sul.

Valdir Caetano e Almerindo Filho, os políticos em questão, elegeramse pela primeira vez no pleito ocorrido em $1^{\circ}$ de outubro de 2000 , quando disputaram com 411 candidatos uma das vagas da casa legislativa em questão, na ocasião composta por 33 vereadores, com mandatos de quatro anos. ${ }^{3}$

Imediatamente após o pleito, os comentaristas políticos da capital gaúcha não deixaram de identificá-los como as "grandes surpresas" das eleições, por serem sujeitos até então desconhecidos da maioria da população. Cabe lembrar, todavia, que esta não foi a primeira vez que religiosos ligados a este segmento ocuparam cadeiras no legislativo porto-alegrense, sendo este, inclusive, um fato recorrente em diversas casas parlamentares de diferentes instâncias pelo Brasil afora. ${ }^{4}$ Todavia, é indispensável ressaltar que o sucesso eleitoral de ambos os pastores foi fruto de uma elaboração bastante cuidadosa da estratégia das "candidaturas oficiais", adotada pela IURD desde 1997. Além de usar seus cultos e veículos midiáticos para divulgar os nomes dos "seus" candidatos, os dirigen tes desta denominação religiosa efetivaram um exercício de acentuada racionalidade política, dividindo a cidade conforme bairros e igrejas, de forma que cada parte apoiasse um dos disputantes (Oro, 2001).

\footnotetext{
${ }^{3}$ Mudanças na legislação, que estarão em vigor a partir da legislatura que se iniciará em 2005, aumentaram para 36 a quantidade de parlamentares na Câmara Municipal de Porto Alegre.

${ }^{4}$ Apenas como ilustração, lembremos que o jornal Folha de São Paulo especulou que, nas últimas eleiçôes gerais, a bancada evangélica na Câmara Federal teria chegado a aproximadamente 60 cadeiras (matéria de 10/10/2002).
} 
Tentemos, para fins de esclarecimento, esboçar um breve perfil destes "políticos religiosos".

Valdir Caetano é natural de São Paulo, tem 48 anos e chegou a Porto Alegre em 1996. Casado e pai de dois filhos, ${ }^{6}$ é pastor da Igreja Universal do Reino de Deus desde 1999. Apresenta um programa matinal na Rádio Capital, intitulado Nosso Tempo e veiculado de segunda a sexta-feira. Gosta de ressaltar que a atividade radiofônica é muito importante para "travar contato com o povo", u ma vez que através do programa tem a possibilidade de atender solicitações dos ouvintes, responder suas dúvidas e saber quais são os problemas que os afligem.

Caetano conta que sua família de origem era humilde, e que exerceu a profissão de metalúrgico durante 17 ou 18 anos. "Só na Ford de São Paulo, na Ford de São Bernardo, trabalhei dez anos”, ele relata.

O sucesso obtido nas urnas foi notável: este pastor, na época filiado ao PTB (Partido Trabalhista Brasileiro), obteve 10.913 votos nas eleições de 2000, constituindo-se no terceiro candidato mais votado dentre todos os que participaram do pleito daquele ano. Ainda assim, o vereador, atualmente no PL (Partido Liberal), considera que o resultado frustrou as expectativas, uma vez que diz que o trabalho foi muito bem feito e esperava uma resposta mais positiva dos "irmãos".

Almerindo Filho nasceu em Montenegro, tem 43 anos e possui formação profissional como Técnico Contábil. Pastor da IURD desde 1996, mi-

${ }^{5}$ Oro (2003) elaborou u ma tipologia diferencian do os "religiosos políticos" dos "políticos laicos". Enquanto os primeiros "exerciam suas atividades religiosas antes de entrar na política, suas eleições se deram em razão do apoio dos fiéis de suas denominações e, atualmente, sustent am ao menos em parte sua identidade religiosa na prática política” (Oro, 2003, p. 2-3 - tradução nossa), os dema is consideram as crenças e convicções religiosas importantes, mas não as têm como fundamentais para o exercício de suas atividades parlamentares.

${ }^{6}$ Conforme o site da Câmara Municipal de Porto Alegre: "Nasceu em São Paulo, à 24/11/ 55, filho de Gerson Caetano da Silva e Zulmira Maria de Jesus, casado com Tereza Maria dos Santos Caetano e têm as filhas Angélica e Sarah.” (Fonte: http:// www. camarapoa.rs. gov.br/frames/veread/pages/valdir.h tm - acesso em 28/10/2004)

Debates do NER, Porto Alegre, ano 5, n. 6, P. 83-112, Dezembro 2004 
nistrou cultos em diversas cidades, como Dom Pedrito, Esteio e Viamão, sendo que era responsável por uma igreja no bairro Tristeza desta última localidade antes de se lançar como candidato à vereança pelo PFL (Partido da Frente Liberal). É presidente da ASSUEC (Associação Universal dos Empresários Cristãos do Rio Grande do Sul) que, conforme indica o nome, é uma associação que congrega empresários vinculados a IURD, possuindo sede em Porto Alegre e atuando em várias cidades do interior do Estado.

Pastor Almerindo foi eleito com a também significativa quantia de 7.645 votos. Numa avaliação diferente daquela feita por seu colega de Universal, este vereador, atualmente membro do PSL (Partido Social Liberal), gostou bastante dos resultados, ressaltando que "pra quem dois meses e meio antes não era nem conhecido em Porto Alegre, a minha campanha foi em dois meses e meio (...), quer dizer que foi um trabalho muito forte".

\section{CONTEXTUALIZANDO A CAMPANHA}

No momento em que pretendemos lançar um olhar etnográfico sobre a campanha destes políticos evangélicos, é indispensável principiarmos lembrando do caráter peculiar da aliança na qual se viram envolvidos. Os pesquisadores dedicados ao estudo da inserção pentecostal na política por diversas vezes ressaltaram a relação tensa que as denominações deste segmento religioso - dentre as quais merece destaque especial a Igreja Universal do Reino de Deus - mantinham com políticos de esquerda, sobretudo com o Partido dos Trabalhadores(PT). Em relação às eleições presidenciais de 1989, por exemplo, as primeiras a se definir por votação direta após praticamente 30 anos, Mariano e Pierucci (1996) demonstram como os líderes evangélicos se posicionaram explicitamente a favor de Collor, do Partido da Reconstrução Nacional (PRN), e contra Lula, do PT, embasados numa interpretaçáo que identificava este último como símbolo de intolerância religiosa, ora sendo vinculado aos regimes socialistas de inspiração soviética, "ateus e perseguidores do Evangelho", ora sendo visto como representante de uma hegemonia católica, extremamente prejudicial ao avanço evangélico. Ocorreu, especial- 
mente no segundo turno, um engajamento tal na campanha de Collor que a política foi levada para dentro dos templos, estando presente na pregação de bispos e pastores de instituições como a IURD a necessidade de "escolher bem” o próximo presidente da República.

Com o passar do tempo, todavia, PT e IURD iniciaram uma aproximação lenta e gradual: sobretudo a partir do segundo mandato de Fernando Henrique Cardoso, em 1998, o partido e a igreja manifestaram concordância em diversos posicionamentos em relação ao Governo Federal. Tal fato tornou-se especialmente notável nas votações no Congresso Nacional em que os parlamentares do bloco evangélico liderado pelo então coordenador político da IURD, deputado federal Carlos Rodrigues (PL/RJ), estiveram lado a lado com os integrantes daquele que, na ocasião, era o maior partido de oposição a FHC. Uma fala de Rodrigues em fevereiro de 2000, no dia do vigésimo aniversário do PT, pode ser considerada paradigmática: o deputado ressaltou o quanto sua igreja anteriormente combatia o partido sem conhecê-lo, confessando que finalmente havia se dado conta de que "lutavam pela mesma coisa”. Destacou, então, que a busca por um mundo mais fraterno e justo os aproximava, dizendo que isto explicava o fato do PL ter acompanhado o PT em 90\% das votaçóes ocorridas durante a legislatura em questão (Freston, 2001). Assim, nas eleições presidenciais de 2002, se inicialmente esteve ao lado do evangélico Anthony Garotinho (então no Partido Socialista Brasileiro), no segundo turno Rodrigues manifestou publicamente seu apoio a Lula, chegando inclusive a atuar como um mediador entre o candidato e lideranças de diversas igrejas evangélicas.

Voltando, então, ao caso porto-alegrense: Almerindo Filho e Valdir Caetano demoraram algum tempo até se posicionarem claramente em relação ao governo municipal: aproximadamente até a metade do mandato, preferiam ser vistos como "independentes", e não como in tegrantes da "situaçãa" ou da "oposição". Importa destacar que, atuando desta forma, os pastores-vereadores se defrontaram com uma série de dificuldades, decorrentes, sobretudo, do fato de neste início de mandato terem sua identidade religiosa bastante explicitada, ocorrendo até mesmo seu emprego como categoria de acusação nos debates ocorridos em plenário. Com o passar do 
tempo, ambos os parlamentares acabaram por modificar sua atuação, de uma certa forma "adaptan do-se" às reg ras do campo político e tornando-se mais próximos dos "políticos laicos".

Neste processo, ressaltamos que, em meados de 2002, alguns meses antes das eleições gerais que ocorreriam em outubro, Caetano e Almerindo, insatisfeitos com os governos estadual e municipal, ambos do PT, passaram a atuar de forma mais integrada com os vereadores que formavam o chamado "bloco de op osição" na Câmara Municipal. Assim, passaram a ser enxergados pelos colegas como políticos que estavam deixando suas opções religiosas num segundo plano e buscando alianças, não sendo, deste então, alvos de críticas e questionamentos públicos acerca de seu pertencimento à Igreja Universal. Todavia, a eleição de Lula, cujo vice é José Alencar, exsenador do PartidoLiberal, sigla que abarca boa parte dos políticosiurdianos, trouxe consigo alteraçóes notáveis neste quadro. Em agosto de 2003, seguindo diretrizes das executivas nacionais dos seus partidos, ${ }^{8}$ ambos os vereadores-pastores não só deixaram de integrar a "oposiçáo" como se aliaram ao bloco governista do parlamento municipal. Este novo posicionamento acarretou diversas críticas da parte dos oposicionistas que, em meio às discussóes sobre esta "alteração brusca", chegaram até mesmo a trazer à tona novamente o pertencimento religioso dos vereadores do PL e do PSL. Não deixa de ser bastante significativo o fato de, após essas mudanças, situacionistas como Raul Carrion, do Partido Comunista do Brasil (PC do B), terem utilizado a tribuna para defender Almerindo Filho, Valdir Caetano e, até mesmo, a Igreja Universal do Reino de Deus.

Neste contexto, mesmo que tenham chegado a travar negociações com o Partido Democrático Trabalhista (PDT), Caetano e Almerindo concorreram no pleito de 2004 como integrantes da coligação denominada Frente

\footnotetext{
${ }^{7}$ Para uma discussão acerca da lógica própria do campo político e das regras às quais os agentes que nele atuam têm de se submeter, ver Bourdieu (1989).

${ }^{8}$ O PL de Valdir Caetano e o PSL de Almerindo Filho estão coligados nacionalmente.
} 
Popular, ${ }^{9}$ cujos candidatos a prefeito e vice eram, respectivamente, o deputado estadual Raul Pont (PT) e a deputada federal Maria do Rosário (PT).

\section{PANFLETOS E TELEVISÃO}

Uma das características mais marcantes da campanha eleitoral destes políticos religiosos foi uma divisão bastante explícita entre atividades "dentro" e "fora" da igreja. Tanto os discursos em torno da candidatura, feitos pelo parlamentar e por seus apoiadores, como os materiais impressos distribuídos aos eleitores em potencial variavam bastante conforme o ambiente, sendo especialmente notável o fato de haver uma escolha cuidadosa dos momentos em que a identidade religiosa do político devia ser acionada. Além disso, não podemos deixar de destacar as peculiaridades acarretadas pela coligação dos partidos destes vereadores com o PT, responsável por situaçōes outrora inimagináveis para um "político evangélico" no Brasil.

Uma observação do material distribuíd o nas ruas e nos gabinetes, por exemplo, tornava difícil para uma pessoa desavisad a identificar vínculos de Almerindo e Caetano com qualquer tipo de organização religiosa. Como podemos verificar nas figuras 1 e 2 , os "santinhos" dos dois parlamentares seguem um padrão que não difere muito daquele verificado entre "candidatos laicos": uma foto do político, sorridente, acompanhada pelo seu número e pela indicação da chapa majoritária à qual está vincul ado - no caso, aquela de Raul Pont e Maria do Rosário. Além disso, ambos apresentavam os símbolos e as cores de seus partidos políticos e, no caso de Almerindo, o slogan "Conquistando o seu voto!", utilizado ao longo de toda a campanha.

\footnotetext{
${ }^{9}$ Além do PT, do PL e do PSL, integravam a coligação o PC do B, o PCB (Partido Comunista Brasileiro), o PMN (Partido da Mobilização Nacional) e o PTN (Partido Trabalhista Nacional).
} 

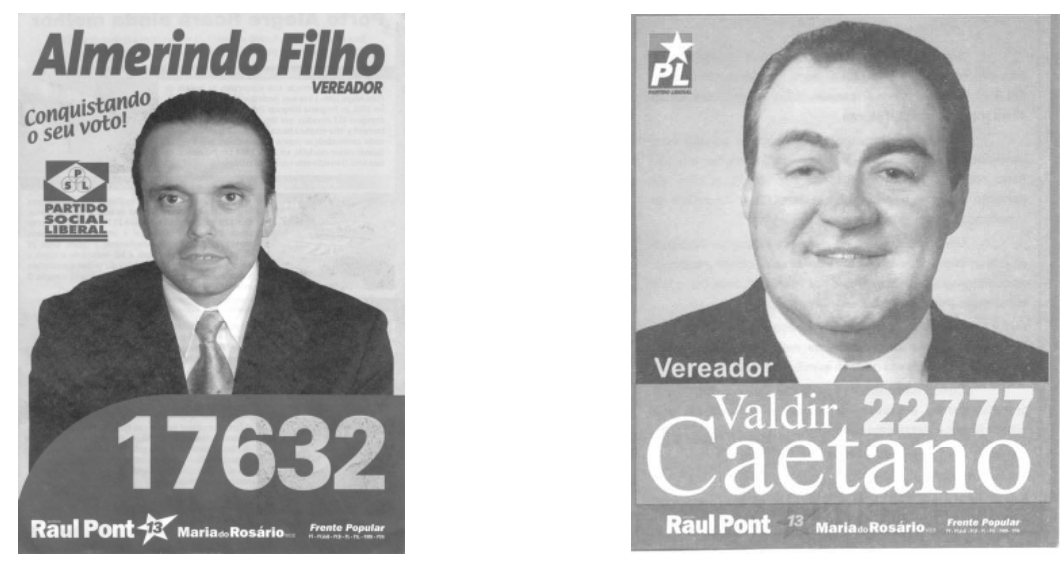

Figuras 1 e 2 - "Santinhos" de Almerind o Filho e Valdir Caetano

Em relação ao verso do panfleto, tivemos acesso a dois modelos diferentes para cada candidato. No primeiro, havia apenas uma divulgação da candidatura majoritária, onde eram apresentados alguns dos principais projetos dos candidatos petistas para a capital gaúcha, como a construção de um conjunto habitacional na entrada da cidade, a complementação viária da Terceira Perimetral e a limpeza dos esgotos e do Rio Guaíba.

Outro modelo apresentava uma espécie de "prestação de contas" do mandato dos vereadores, listando o que consideravamsuas principais realizações. Valdir Caetano principiavalembrando dos votos que fez no último pleito muniapal,ressaltando também os 213 mil que obteve quando se candidatou ao Senado, em 2002, 47 mil dos quais "só na capital gaúchä. Destaca também o fato de ter exercido o cargo de segundo vice-presidente da Câmara Municipal por dois anos consecutivos, além de ser líder da bancada e presidente metropolitanodo PartidoLiberal. Por fim, ressalta os projetos apresentados ao longo do seu mandato, destacando aqueles que determinam a instalação de câmeras de vídeo em pontos estratégicos da cidade, com a intenção de coibir a criminalidade, e a substituição dos "pardais" por "lombadas eletrônicas" na aferição da velocidade dos veículos. Neste material, o elemento religioso surge apenas no momento em que Caetano cita outra 
proposta, aprovada, que garante "isenção de IPTU para os imóveis, alugados ou próprios, de entidades beneficentes, hospitalares, religiosas (todas), sem fins lucrativos" (grifo nosso). Por fim, o vereador destaca sua defesa da educação dos jovens e adultos, afirman do que esta é sua grande "bandeira".

Almerindo Filho, por sua vez, apresentava-se como pastor evangélico, sem, todavia, prestar qualquer esclarecimento em relação à sua filiação institucional. Um destaque muito maior foi dado aos projetos que explicitam a "preocupação social" que o vereador faz questão de ressaltar como grande marca de seu mandato. Assim, o político do PSL lista projetos de distribuição de medicamentosgenéricos a pacientes carentes possuidoresde enfermidades crônicas, de elaboração de políticas de atenção integral à saúde dos diabéticos, de incentivo à doação de sangue e de fornecimento de material escolar para crianças cujos pais ou responsáveis sejam portadores de HIV. Almerindo cita como uma de suas maiores realizações a criação do "Projeto Mão Amiga", o qual "leva a centenas de famílias serviços como: atendimento jurídico gratuito, orientação de saúde do idoso e da mulher, encaminhamento para empregos e retirada de documentos ( $2^{\mathrm{a}}$ via), corte de cabelos, etc.”

As apariçóes de ambosos candidatos no horário eleitoral gratuito também não fugiam muito de um padrão "não-religioso" de apresentação. Todavia, antes de olharmos com mais atenção para as falas dos pastores-vereadores, devemos ressaltar que a distribuição de tempo nos programas de TV foi alvo de polêmicas durante a campanha:segundo matéria publicadano jornal ZeroHora (09/09/2004), outroscandidatosdo PL chegaram até mesmoa entrarcom um pedidona JustiçaEleitoral, exigindouma divisãomais igualitária.LuizNegrinho, SérgioSelister, Roni da Silvae Nelson Neves de Souzareclamavam que, dos 60 segundos destinados ao PL, 45 estariam sendo utilizados por Valdir Caetano. Além disso,conforme os reclamantesrelataramao periódico, durante a semana em questão " 26 segundos de espaçoda propaganda na TV teriamsido cedidos por Caetano ao pastore vereador Almerindo Filho, do PSL, também integrante da Universal" (Zero Hora, 09/09/2004). Em resposta, a coordenação da Frente Popular alegouque a denúncia não tinha procedência,afirmando que o tempo originalmente acordado para o PL era mesmo de 60 segundos e um acordo destepartido com o PT haviadeterminado que cadaum cederia doisou 
três segundos para ampliar um poucoo espaçodo PSL. Este impasse, classificado por Zero Hora como "mais um episódio no conflito entre integrantes da Igreja Universal e os demais filiados do PL no Estado", não foi adiante, ao menos até onde tivemos informaçôes: as apariçôes de Caetano prosseguiram maiores do que aquelas dos demais candidatos. Este talvez tenha sido o único momento, nesta campanha, em que as tensões entre o religioso e o político vieram a público de uma maneira mais explíata.

Tomando como referência uma observação atenta das aparições de candidatos com vinculações religiosas no horário eleitoral gratuito durante a campanha de 2000, Oro (2001) nos apresenta um esboço da imagem que os candidatos da IURD expunham publicamente na ocasião. $\mathrm{O}$ autor verificou que Valdir Caetano falava brevemente de seu trabalho social, mas não expunha nenhuma identificação religiosa específica, de forma que aqueles que não o conhecessem anteriormente não teriam como saber de sua condição de evangélico. Almerindo, por sua vez, apresentava-se como pastor evangélico, mas não esclarecia a qual denominação estava vinculado. As terminologias religiosas estavam pouco presentes nas duas campanhas, manifestando-se apenas em algumas poucas expressões, como o slogan "Fé para mudar" repetido pelo então candidato do PFL (Partido da Fren te Liberal).

$\mathrm{Na}$ campanha deste ano, Caetano e Almerindo apareciam na televisão três vezes por semana, no espaço dedicado aos vereadores da Frente Popular. Desta vez, nenhum dos doisse apresentou como "pastor" ou representante de segmentosreligiosos. A idéia, ao que parece, era também neste espaço efetivar uma "prestação de con tas" listando as principais ações de cada mandato. Em virtude da divisão acima mencionada, o vereador do PL tinha mais tempo e, além disso, optou por gravar uma maior variedade de mensagens. Ao longo de nosso acompanhamento dos programas de TV, identificamos cinco falas diferentes de Valdir Caetano e duas de Almerindo. ${ }^{10}$ Vestindo terno preto, camisa branca e gravata vermelha, o representante do Partido Liberal falava

\footnotetext{
${ }^{10}$ Infelizmente não pudemos acompanhar todos os programas do horário eleitoral, em virtude de outros compromissos e atividades que tínhamos no momento em que o programa era transmitido.
} 
no mesmo cenário usado por todos os outros candidatos da Frente Popular, onde se destacavam os nomes e o número de Raul Pont e Maria do Rosário. Sua única peculiaridade, neste momento, era a música característica dos comerciais de seu partido, que servia como pano de fundo para suas palavras. A primeira das aparições deste vereador, por sinal, é bastante paradigmática do teor assumido pela "face pública" de sua campanha:

Amigo porto-alegrense, sou o vereador Valdir Caetano. Concorro à reeleição pelo Partido Liberal, com o número 22.777. Tenho a convicção de que honrei os votos que recebi. No próximo mandato continuarei comprometido com as causas da nossa cidade. Tenho a certeza que é pela educação que se fará a verdadeira revolução. Educação é a solução. Vote sem engano, vote Valdir Caetano, 22.777! (Sorrindo e fazendo gesto de positivo com os polegares)

Como podemos ver, o político se apresenta como alguém "comprometido" com Porto Alegre, cujo envolvimen to com as "causas da cidade" dá a certeza de que teve uma atuação "honrada". Assim, simpático e sorridente, Caetano listou algumas das "grandes realizaçoes" de seu mandato: trata-se justamente daqueles projetos já citados em seu material impresso. Numa de suas últimas apariçôes, o pastor-vereador fez a única menção ao tema "religião":

(...) É de minha autoria a lei aprovada em dezembro de 2002, que isenta de IPTU os prédios de todas as igrejas, resolvendo assim um problema existente há muito tempo. Portanto, prezado líder religioso, se a tua igreja ainda não recebeu esse beneficio, me procure em meu gabinete que terei prazer em lhe atender. (...)

Atentemos para o fato de que, como já estava implícito na referência a este projeto em seu "santinho", Valdir Caetano se dirigia aos líderes "de todas as igrejas", sem especificar seu pertencimento religioso ou menci onar qualquer tipo de predileção por um segmento ou outro. Compreendemos tal atitude, complementada pela sugestão de que os interessados podem procurar o gabinete para obter orientação, como uma estratégia utilizada por este político para simultaneamente demonstrar em público sua preocupação com as organizações religiosas, atitude que certamente deve agradar 
suas "bases eleitorais", e evitar as acusações de sectar ismo que tanto atingiram ambos os representantes da IURD no início de seus mandatos. Em outra de suas aparições, Caetano destacou o conhecimento que possui dos limites da atuação de um vereador: “(...) Não vou prometer o que o vereador não pode cumprir. A competência do vereador está definida na Lei Orgânica do Município: a ele cabe fiscalizar o bom uso das verbas públicas, propor e votar projetos de lei que melhorem a vida do povo". Tal esclarecimento repercutiu de forma bastante positiva na mídia, chegando até mesmo a resultar em elogios da comentarista política do grupo RBS, Rosane de Oliveira. Como veremos a seguir, este "reconhecimento" foi visto como uma grande vitória pelas lideranças da Igreja Universal.

No último dia do horário eleitoral, o candidato do PL apresentou uma fala especial, agradecendo pelas "milhares de manifestaçôes de carinho, de atenção e apoio recebidas dos porto-alegrenses", garantindo que, num eventual novo mandato, continuaria "comp rometido com a nossa cidade". Por fim, no gesto mais "religioso" de sua campanha televisiva, despediu-se desejando que "Deus abençoe a todos".

Almerindo Filho, por sua vez, não deixou sua identidade religiosa transparecer nem sequer indiretamente em suas apariçōes na televisão. Foram apenas duas as falas deste pastor-vereador que conseguimos registrar, ambas consideravelmentecurtas e sintéticas. Trajandoterno azul-escuro,camisa branca e uma gravata listrada em branco e azul-marinho, o representante do PSL também usava em seus pronunciamentos o cenário padrão da Frente Popular:

A distribuição gratuita de medicamentos genéricos e a criação da cesta básica do idoso estão entre os principais projetos de meu primeiro mandato. Quero conquistar seu voto e continuar a dedicar meu trabalho às comunidades carentes. Vote 17.632, Almerindo Filho.

Hojequerofalar com você que nestesquatro anos foi atendido em meu gabinete ou recebeu nossa visita em sua comunidade. Ao todo, foram mais de 2000 pessoas atendidas.Quero continuarcom essetrabalho. AlmerindoFilho, 17.632.

A ênfase, portanto, novamente foi colocada sobre o "trabalho social" executado pelo gabinete do vereador. Se na primeira aparição Almerindo cita 
projetos voltados para a resolução de problemas da "população carente", na segunda foi ainda mais explícito, dirigindo-se diretamente àquelas pessoas que foram atendidas em suas comunidades ao longo dos quatro anos de seu mandato. Como podemos inferir cotejando esta fala com o conteúdo dos "santinhos" expostos acima, as ações do "Projeto Mão Amiga" têm uma centralidade notável na avaliação que o próprio político do PSL faz de suas realizaçôes. Assim, este vereador-pastor tenta construir sua legitimidade enquanto postulante à reeleição através da publicização de uma preocupação com os "necessitados", evidenciando ações que o político pode ter "fora do plenário". ${ }^{11}$ Por outro lado, lembremos que o "trabalho social" de forma alguma prescinde da estrutura da igreja: devemos ter em conta que, mesmo sem ser citado na propaganda eleitoral, o apoio de lideranças religiosas e "empresários cristãos" é indispensável para o sucesso de tais atividades.

Observando este contexto, podemos nos remeter ao trabalho de Karina Kuschnir (2000), que, em sua pesquisa sobre a Câmara Municipal do Rio de Janeiro, demonstra como a "obrigação de aten der" é decorrência da necessidade dos políticos de reafirmar constantemente seu prestígio perante as "comunidades" às quais estão vinculados. Ao mesmo tempo, Maria das Dores C. Machado (2003) relaciona a crescente ênfase nas "ações sociais" com as estratégias expansionistas adotadas por igrejas pentecostais e neopentecostais a partir da década de 1990. Em relação ao caso específico da IURD esta autora argumenta que

(...) o cuidado sistemático da liderança dessa denominação na divulgação de suas ações sociais é uma decorrência da necessidade de criar um mecanismo de legitimação para o grupo, mas que certamente tem a ver também com a conjuntura sociopolítica do país. (Machado, 2003, p. 304)

Neste sentido, pensamos que a importância dada pelas lideranças evangélicas ao seu ingresso na política institucional se deve, em grande parte, às

${ }^{11}$ Isto, inclusive, é utilizado como argumento nos debates no parlamento e na imprensa em que a "baixa assiduidade" dos vereadores evangélicos, tidos como bastante ausentes das sessões, é discutida.

Debates do NER, Porto Alegre, ano 5, N. 6, P. 83-112, DeZembro 2004 
possibilidades que passam a ter de abrir diversos canais de mediação com instituiçôes públicas e privadas dispostas a participar de uma complexa rede de compromissos recíprocos. ${ }^{12}$

\section{A CAMPANHA NO CULTO}

Se a propaganda televisiva e o material impresso revelam uma faceta predominantemente laica da campanha dos pastores-vereadores, a observação de alguns cultos e o acompanhamento de eventos nos quais ambos os políticos se fizeram presentes revela uma realidade bem diferente. Inicialmente, é essencial termos em conta o fato de que, mais uma vez, os estrategistas políticos da Igreja Universal tiveram o cuidado de dividir as zonas eleitorais da cidade entre seus dois candidatos: geograficamente, o Centro e o Norte ficaram com Valdir Caetano, enquanto o Sul e o Leste, maiores territorialmente, porém menores em termos populacionais, foram destinados para Almerindo Filho. Seguindo esta divisão, cada político teve à sua disposição, como "base" para as movimentaçôes de campanha, um dos grandes templos que a Universal possui em Porto Alegre: a Catedral da Fé, estrategicamente localizada no centro da cidade, nas proximidades de paradas de ônibus, da estação rodoviária e de um dos principais pontos do trem metropolitano, era o grande ponto de concentração dos apoiadores de Caetano, enquanto a Catedral da Azenha, de menores proporçôes, recentemente inaugurada na Avenida Oscar Pereira, num dos bairros de maior movimento da cidade, cumpriu a mesma função para os simpatizantes de Almerindo. Assim, se durante a semana percorriam os cultos de diversas igrejas de suas "regióes", nos domingos os pastores-vereadores se ded icavam a estes pontos onde o afluxo de público era bastante elevado.

No dia 5 de setembro, por exemplo, a pouco menos de um mês das

12 Poderíamos tratar este fenômeno empregando categorias analíticas tradicionais como clientelismo e corporativismo, mas, seguindo o conselho de pesquisadores como Bezerra (1999) e Kuschnir (2000), consideramos importante relativizar o emprego destes termos, comumente utilizados tanto no senso comum como nos trabalhos acadêmicos.

Debates do NER, Porto Alegre, ano 5, N. 6, P. 83-112, Dezembro 2004 
eleições, o bispo que coordenava o culto dominical das 10 horas da manhã na Catedral da Fé dedicou aproximadamente 15 minutos para falar sobre a importân cia das eleiçôes e do voto nos "can didatos cristãos". Para tanto, chamou Valdir Caetano até o palco, chamando-o de "nosso pastor" e apresentando-o como um "Homem de Deus", escolhido para sua "missão" pela intervenção das forças divinas. Ou seja: ele não estava na política por vontade própria, mas porque Deus assim ordenou. Na seqüência, o pastor leu para aos fiéis uma nota publicada na coluna da articulista política Rosane de Oliveira, do jornal Zero Hora. Tratava-se justamente da matéria que citamos anteriormente, em que a colunista elogiava o fato de Valdir Caetano afirmar na sua propaganda política que não iria propor nada que não estivesse na alçada de um vereador. Com isso, o bispo quis demonstrar como o então candidato à reeleição estava repercutindo fora do âmbito da igreja, entre os não-crentes. Esta "atuação destacada" estaria ocorren do, conforme o líder religioso, porque, diferentemente dos outros políticos, que seriam enganadores e corrompidos por "não deverem nada a ninguém", os religiosos estariam obrigados a "prestar contas a Deus e aos irmãos", situ ação que lhes colocaria como fortes opositores dos "demônios" que assolariam as instâncias políticas do país. ${ }^{13}$ Para finalizar, o bispo convidou todos os presentes a fazerem uma oração em prol de Valdir Caetano: com a mão sobre a cabeça do vereador, o ministro religioso invocou as bênçãos de Deus para a candidatura, palavras que eram repetidas em coro pelas cerca de duas mil pessoas presentes no templo. Interessante destacar que o próprio Caetano nada falou durante o evento, apenas permanecendo de pé ao lado do bispo.

$\mathrm{Na}$ seqüência, os obreiros da igreja entregaram aos fiéis um livreto, in ti tulado "Voto de Fé- união evangélica em favor do povo" (ver Figu ra 3).

$\mathrm{Na}$ capa, havia uma série de imagens remetendo ao conceito de uma "identidade gaúcha": bota, rodas de carroça, colheitadeira, a bandeira do Estado. Ficava claro, assim, de qual "povo" se estava falando. Nas primeiras páginas tínhamos pequenos textos do deputado estadual Sérgio Peres e do

${ }^{13}$ Acerca do imaginários das "forças invisíveis", bastante difundido entre segmentos evangélicos na América Latina, ver Corten e Mary (2000).

Debates do NER, Porto Alegre, ano 5, N. 6, P. 83-112, DeZembro 2004 


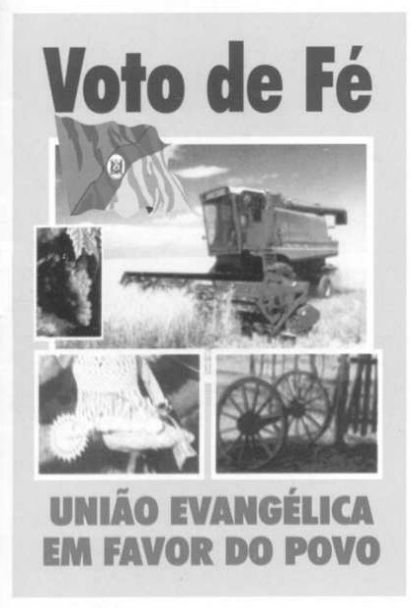

Figura 3 - Livreto distribuído nos cultos da IURD durante o período eleitoral
Bispo William, que davam seu apoio e pediam votos para Valdir Caetano. O próprio vereador não deixava de se pronunciar, dessa vez adotando um tom bastante diferente da "campanha laica" que verificamos em outros contextos:

Prezado(a) Irmão(ã). Estou na política não por vontade ou interessepessoal, mas sim para cumprir uma missão que foi delegada pelo povo cristão, qual seja, a defesa das suas causas, assegurando a liberdade de culto religioso, combatendo a intolerânciacontra nossa igreja e outras que nos são caras. É para isto que sou vereadorde Porto Alegre e agora, indicado para concorrer a reeleição venho pedir o teu voto e o trabalho de multiplicação dos votos da fé. A tua atuação será uma oferta de amor e dedicação à nossa causa e luta.

Como podemos ver, Caetano se di rige diretamente aos "irmãos de fé", ressaltan do que seu ing resso na política se deve ao "povo cristáo" e lembrando das açôes em sua defesa que um mandato parlamentar permite realizar. Para que assim continue, manifesta a necessidade de contar com a dedicação de todos ao "trabalho de multiplicação": no livreto em questão havia sete pequenos questionários com perguntas como nome, endereço e título de eleitor. Estes espaços deviam ser preenchidos pelo fiel e por mais seis pessoas que ele convencesse a votar em Valdir Caetano. Posteriormente, já preenchidos, os livretos deveriam ser entregues na igreja, o que daria às lideranças uma prévia da quantidade de votos disponíveis e do perfil dos eleitores do candidato. As palavras do Bispo William, colocadas logo após sua foto e a citação bíblica de Provérbios, 29:2 ("Quando se multiplicam os justos, o povo se alegra, quando, porém, domina o perverso, o povo suspira"), tentam reforçar a importância do "voto evangélico": 
Com o presente livro, pedimos além do seu voto, como uma oferta à nossa obra, também a multiplicação do voto, pela conquista de outros votos, o que tornará o nosso candidato o mais votado da cidade, com o que seremos mais respeitados como organização que realmente tem capacidade eleitoral e assim influência na comunidade onde atuamos.

Explicita-se, aqui, a intenção de contar com representantes cuja votação e visibilidade garantam mais "respeito" e "influência" para a igreja. Tal afirmação sempre esteve presente nos diálogos que travamos com estes sujeitos, sendo repetida inúmeras vezes por líderes religiosos, políticos e assessores ao longo de nossa pesquisa. Além disso, à maneira do que sugere Oro (2001), podemos perceber neste texto u ma notável "sacralização do voto", id en tificado como mais uma das "ofertas" necessárias para a continuidade da "obra da igreja". Consideramos indispensável destacar, também, que, conforme relataram informalmente nossos interlocutores, este livreto foi adotado em todos os municípios do Rio Grande do Sul onde a IURD lançou "candidatos oficiais", sendo que as mensagens do Bispo William e do Deputado e Pastor Sérgio Peres ${ }^{14}$ se repetiam, sendo substituído apenas o "recado" do candidato a vereador.

Desta forma, não há nada de surpreendente no fato de, ao participar de um culto dominical na Catedral da Azenha, também termos recebido semelhante livreto: a única diferença era uma mensagem pessoal de Almerindo Filho, que novamente destacava o "Projeto Mão Amiga" e as realizaçóes de seu mandato, obtidas apesar da "falta de experiência política". Encerrando seu "recado", o representante do PSL pedia: "Com fépara mudar e vencer, na defesa do evangelho e do povo de Deus, vote: Pr. Almerindo Filho - 17632”.

\footnotetext{
${ }^{14}$ Apenas para exemplificar o teor "genérico" desta mensagem, que não se refere apenas à cidade de Porto Alegre, citemos um trecho do que diz Sérgio Peres: após agradecer a "generosidade" deseus "irmãos evangélicos", que o colocaram na Assembléia Legis lativa, o pastor-deputado faz o pedido: "Converse com seus parentes, amigos, colegas de trabalho e conhecidos, conquiste o voto deles, traga-os para a nossa causa, diga a eles da seriedade e do comprometimento do(a) nosso(a) candidato(a) com o teu município. (...) Tenho certeza que Deus te capacitará para esta missão.”
} 
Ressaltemos, também, que na contracapa do material em questão havia uma foto daquele que vem se consolidando como o novo líder político da Igreja Universal: o bispo Marcello Crivella, do Rio de Janeiro. ${ }^{15}$ Visando, mais uma vez, referendar biblicamente a necessidade de se ter "homens de Deus" na política, havia ali também uma frase retirada do Livro dos Provérbios (15:22): "Onde não há conselhos fracassam os projetos, mas com os muitos conselheiros há bom êxito".

\section{CAMINHADAS E “BANDEIRAÇOS”}

Os dois vereadores evangélicos de Porto Alegre promoveram atividades comuns àquelas realizadas pelos "políticos laicos": referimo-nos à chamada "campanha de rua", caracterizad a por eventos tais como caminhadas, "bandei raços"16, carreatas e comícios.

No dia 5 de setembro, Almerindo Filho e seus apoiadores realizaram uma cam in hada, cuja "concen tração" ocorreu nas imediações do Estádio Olímpico. Contando com aproximadamente duzentas pessoas, o evento parecia expressaruma necessidadede levar a campanha para um público mais amplo, além do âmbitorestrito da igreja. Contudo,camisetas com mensagens bíblicas

\footnotetext{
${ }^{15}$ A importância de Crivella nos planos políticos da IURD pode ser aferida pelo fato do bispo responsável pelo culto das 10 horas do dia 26 de setembro, na Catedral da Fé, ter solicitado aos presentes que entrassem em contato com amigos e familiares do Rio de Janeiro para solicitar seu voto na candidatura do Bispo à prefeitura daquela cidade. No fim das contas, Crivella, filiado ao PL, ficou em segundo lugar nas eleiçôes, vencidas no primeiro turno por César Maia (PFL). Todavia, é inegável que o líder religioso obteve uma votação considerável: 753.189 eleitores optaram por sua candidatura $(21,83 \%$ do total), enquanto 1.728 .853 (50,11\%) propiciaram a reeleição de Maia.

${ }^{16}$ O termo "bandeiraço" é utilizado para designar as ocasiōes em que os cabos eleitorais de um determinado candidato reúnem-se numa via pública, preferencialmente bastante movimentada, e lá permanecem por certo período de tempo agitando bandeiras e distribuindo material de propaganda. Às vezes a atividade conta com o acompanhamento de um carro de som, através do qual é reproduzido o jingle do político e/ou são apresentadas suas realizaçóes e propostas.
} 
e símbolos da IURD, algumas das quais com a inscrição "Juventude Universal", já denunciavam o fato da maioria dos participantes ser fiel da igreja. Tratava-se, predominantemente, de mulheres e crianças, que percorreram animadamente algumas ruas das imediações, portando adesivos e bandeiras com as cores do PSL, o nome e o número do candidato. Acompanhando todo o trajeto havia um carro de som, coberto de adesivos, incluindo-se um bastante grande, em sua traseira, em que se podia ler o conhecido slogan da Igreja Universal: "Jesus Cristo é o Senhor". Além de reproduzir a música da campanha, os alto-falantes transmitiammensagens que enfatizavambastante o "trabalho social" feito por Almerindo, citando, inclusive, as "mais de 2000 pessoas" que teriam sido atendidas durante seu mandato. Como se já não bastassem os indícios apontados e o fato da caminhada terminar nos arredores da Catedral da Azenha, a vinculação religiosa do candidato tornava-se evidente para qualquer transeunteque prestasseatenção na letra do seu jingle:

Com a benção do Senhor,

Vote Almerindo para vereador.

Com a benção do Senhor,

Vote Almerindo para vereador.

Vote bonito,

Vote lindo.

Vote pastor Almerindo.

Vote bonito,

Vote lindo.

Vote pastor Almerindo.

17632

Vote Almerindo para vereador.

17632

Com a benção do Senhor.

17632

Vote Almerindo para vereador.

17632

Com a benção do Senhor 
Esta música, cantarolada de forma bastante animada por boa parte dos presentesna caminhada,também era executadaao fim dos cultos na Catedral da Azenha, quando o próprio Almerindo Filho cumprimentava os fiéis que estavam saindo do templo, e nos "bandeiraços", geralmente realizados nas imediaçōes do referido templo. Chamando o político de "pastor" e pedindo que o voto seja feito "com a benção do Senhor", a execução pública deste jingle foi um dos raros momentos nesta campanha em que os elementos religiosos foram acionados por um dos candidatos fora do ambiente da igreja.

Valdir Caetano também promoveu "bandeiraços" em torno da Catedral da Fé, sobretudo após os cultos dominicais, e ambos os candidatos promoveram caminhadas em direção ao Brique da Redenção, ${ }^{17}$ tradicional ponto de encontro de militantes e candidatos durante as campanhas eleitorais em Porto Alegre. Este espaço tem uma importância tão grande para os políticos da capital gaúcha que, significativamente, foi o único onde os apoiadores dos dois candidatos se fizeram presentes, deixando momentaneamente de lado a divisão eleitoral da cidade. Assim, em domingos alternados, Almerindo e Caetano levaram sua campanha para o local. O primeiro saía da Catedral da Azenha com seus apoiadores, caminhava pela Avenida João Pessoa, passava pelo Brique e retornava aos arredores da Oscar Pereira, onde ficava por algumas horas fazendo "bandeiraço" com sua militância. A caminhada de Valdir Caetano, por sua vez, seguia outro trajeto, mas igualmente atraía as atençōes dos freqüentadores do local: saindo da Catedral da Fé e percorrendo algumas vias centrais da cidade, o grupo, bastante barulhento e animado, atravessava alguns dos caminhos mais movimentados do Parque da Redenção, antes de chegar ao Brique. Após alguns minutos, tomavam o caminho de volta à Catedral, de onde se dispersavam para alguns "bandei raços" estrategicamente localizados nos arredores.

A internet também foi utilizada por Almerindo Filho como um meio de divulgação da candidatura. No dia 16 de setembro, o vereador promoveu o coquetelde lançamentode seu site (www.almerindofilho.com.br), o qual con-

${ }^{17}$ Trata-se de uma feira de artesanato e antigüidades realizada todos os sábados na rua José Bonifácio, ao lado do Parque Farroupilha, popularmente conhecido como "Parque da Redenção" e tido como u m dos prin cipais locais de lazer da classe média porto-alegrense.

Debates do NER, Porto Alegre, ano 5, N. 6, P. 83-112, Dezembro 2004 
tém informações sobre a campanha e o mandato na Câmara Municipal. O evento teve a presença de representantes de suas "bases eleitorais": líderes comunitários dos bairros onde o vereador realiza o "trabalho social", pastores, obreiros e, destacadamente, o Bispo Paulo Pereira, da IURD. Convidados pela assessoria do parlamentar, quando chegamos ao local, uma churrascaria na avenida José de Alencar, sentamos numa das mesinhas decoradas com flores azuis e amarelas, cores do PSL, e santinhoscom a foto de Almerindo.O vereador, seu chefe de gabinete Cláudio e alguns outros assessores caminhavam pelo salão e cumprimentavam as pessoas, enquanto esperavam a chegada da principal convidada da noite: a deputada federal Maria do Rosário, candidata a vice-prefeita pela Frente Popular.

Após mais de uma hora de espera, durante a qual os presentes conversavam discretamente, em pequenos grupos, a parlamentar finalmente chegou, dando início à cerimônia prop riamente dita. Inicialmente, o pastor-vereador agradeceu aos presentes, citando, inclusive, os "pesquisadores do Núcleo de Estu dos da Religião da UFRGS”, e apresen tou seu site, fazendo uso dos recursos multimídia de um computador conectado a um projetor (data-show). Posteriormente, reforçou a importância do trabalho realizado durante seu mandato e falou sobre a candidatura à reeleição, momento em que citou a aliança com a Frente Popular e apresentou Rosário aos presentes. A deputada disse algumas palavras acerca do trabalho já feito pela prefeitura, defendendo também a tolerância religiosa e de todo tipo. Por fim, ressaltou as qualidades do político evangélico: "A primeira impressão que tivemos do vereador Pastor Almerindo, em visita a Igreja Universal, é de que ele é uma pessoa vencedora. É esse espírito que nós, da candidatura majoritária da Frente Popular, queremos imprimir a todos os cidadãos de Porto Alegre". Depois dos pronunciamentos de Almerindo e de Maria do Rosário, o bispo Paulo foi chamado para fazer uma oração pelas candidaturas do pastor e de Raul Pont. Assim, todos os presentes oraram, de olhos fechados e com as mãos dadas, solicitando que as bênçãos divinas recaíssem sobre o candidato à reeleição.

A partiaipaçãode umaliderançado Partido dosTrabalhadores num evento onde a política e a religião se combinam de forma tão estreita certamente merece alguns comentários à parte. Para compreender este fenômeno, como 
já indicamos,é necessáriolembrar das contribuiçôes de autores como Freston (2001) e Oro (2001), que demonstram como posicionamentos similares em relação à conduta ética na política e aos "problemas sociais" acabaram por aproximar estas instituições que outrora pareciam antagônicas. Ora, um dos resultados mais notáveis desta aproximação, durante o período eleitoral, é o fato dos atores sociais envolvidos passarem a freqüentar ambientes distintos daqueles com os quais estão habituados. Se, por um lado, vemos Maria do Rosário orando ao lado de pastores, bispos e obreiros, por outro assistimos a participação dos vereadores evangélicos em eventos possuidores de uma fortíssima carga simbólica para a esquerda: no caso específico de Porto Alegre, referimo-nos aos comícios da Frente Popular, conhecidos por aglomerar milhares de militantes aguerridos,com suas bandeiras e palavras de ordem de inspiração socialista. Ora, no comício ocorrido na noite do dia 24 de setembro, ao lado da Prefeitura, os cabos eleitorais de Valdir Caetano eram alguns dos mais empolgados, agitando suas bandeiras e gritando o nome do vereador, sobretudo quando este foi citado entre os representantes dos partidos integrantes da Frente Popular. Já no segundo turno, ambos os vereadores se fizeram presentesno comício que encerrou a campanha de Raul Ponte Maria do Rosário,sendo que Almerindo chegou até mesmo a destacar esta atividade numa notícia publicada em seu site.

Não achemos, porém, que esta recente aliança entre o PT e os políticos da IURD ocorre sem resistências. Primeiramente, como já sugerimos, nem todos os integrantes da igreja ficaram satisfeitos com a coligação, devido a confrontos anteriores, que culminaram, inclusive, no apoio à candidatura de Germano Rigotto, do PMDB, adversáriodo petista Tarso Genro no segundo turno da disputa pelo governo do RS, em 2002. Além disso, nos cultos que observamos durante a campanha de 2004, em nenhum momento vimos o pastor solicitar o voto na chapa majoritária: apenas o nome do vereador, o "homem de Deus na política", era citado. Talvez sabendo desta dificuldade, militantes do PT distribuíam, na saída da Igreja, panfletos vinculando Almerindo ou Caetano com Raul Pont, material este que era recebido com expressõesde estranhamento por alguns dos fiéis. Intitulado "Carta aos Evangélicos", o referido panfleto continha um texto anunciando a formação da 
"Fren te Evan gélica em Apoio à Fren te Popular", formada por pastores, obreiros e membros que têm "como objetivo principal defender os interesses de nossas igrejas junto ao poder público". Anunciando a proximidade das eleições e enfatizando a importância deste momento, os signatários pedem aos "irmãos" apoio para a candidatura de Raul Pont:

Temos em nossa capital uma experiência muito positiva de administração, com obras e serviços voltados para os mais pobres, com participação de todos os segmentos sociais. Um projeto que há 16 anos tem feito nossa cidade e a igreja do Senhor Jesus prosperarem. A Frente Popular (...) tem sido amiga das igrejas evangélicas, dando liberdade e incentivo ao culto religioso e às suas obras sociais. (...) Queremos pedir a sua ajuda para que Porto Alegre continue crescendo e para que o Reino de Deus continue sendo propagado com a mesma liberdade e apoio que tem tido até agora.

A mensagem aborda dois pontos muito relevantes para os evangélicos: a preocupação com os "necessitados", marca de uma administração "voltada para os mais pobres", ea liberdade religiosa, garantida por governan tes que afirmam prezar pela tolerância. A avaliação destas questóes tem importância notável na definição das opções eleitorais das lideranças evangélicas, de tal forma que o destaque que recebem nestematerial deve ser vistocomo uma estratégia adotada pelos religiosos ligados ao PT para angariar apoios em meio a segmentos refratários ao tradicional discurso "de esquerda" do partido. O emprego da citação bíblica de Provérbios, 14:31 ("O que oprime o pobre insulta o criador e a este honra o que dele se compadece") e a apresentação de depoimentos do pastor Joel Neves, da Assembléia de Deus de Porto Alegre, do pastor Enéias Gonçalves,da Assembléiade DeusMadureira, do bispoAntônioFidelesMarin, da Igreja Nova Jerusalém, de Marina Silva, evangélica e ministra do Meio Ambiente, bem como dos próprios vereadores ValdirCaetano e Almerindo Filho ${ }^{18}$

${ }^{18}$ Ambos os representantes da IURD enfatizam a questão da liberdade religiosa. Caetano lembra que “(...) a Frente Popular administra Porto Alegre há 16 anos, o que demonstra o respeito e a aprovação dos porto-alegrenses por uma Administração que assegura, às inúmeras denominaçóes religiosas, o respeito e a liberdade de culto", enquanto Almerindo ressalta que "aplena aceitaçãode um vereador evangélico, comprovando o respeito do PT pela pluralidade de crenças e opi niōes, foi decisiva para levar o nosso apoio à Frente Popular”. 
visam reforçar e legitimar o pedido de que os “irmãos de fé" estejam ao lado da Frente Popular.

Não esqueçamos, também, que alguns petistas se mostram incomodados em ver seu partido se aproxi mar com grupos aos quais anteriormente se opunha, manifestand o sua insati sfação com o pragma tismo eleitoral adotado pelos dirigentes nos últimos anos. Não deixa de ser significativo, neste sentido, perceber como militantes com bandei ras vermelhas e camis etas com a image m do revolu cionár io Che Guevara se sentiram incomodados ao verem o pastor Valdir Caetano no mesmo palanque que suas lidera nças. Presenciamos esta situação no últim o comício do primei ro turno, quando alguns destes petistas, em sua maioria jovens aparentando menos de 20 a nos, gritavam "Volta pra igreja!" todas as vezes em que o represe ntante da Igreja Universal era citado pelos aprese ntadores.

\section{O QUE DISSERAM AS URNAS}

Os últimos atos das campanhas de Valdir Caetano e Almerindo Filho reafirmaram a divisão eleitoral da cidade: no sábado, dia 2 de outubro, véspera do pleito, os dois realizaram carreatas, cada uma passando pelas principais ruas de alguns bairros que constituíam a "sua" parte da cidade. No dia seguinte, terminada a apuração, os resultados finais revelaram que ambos conseguiram se reeleger: Almerindo com 6342 votos, Caetano com 10138. Para conferir o quão eficiente foi a estratégia eleitoral das lideranças iurdianas, nada melhor do que verificarmos a votação dos candidatos na diferentes zonas eleitorais de Porto Alegre. Com a intenção de identificar possíveis alterações ocorridas no intervalo de quatro anos que separa uma eleição da outra, optamos por colocar lado a lado os dados de 2000 e 2004. 
Tabela 1 - Votos de Almerindo Filho nas eleições de 2000 e 2004, por Zona Eleitoral

\begin{tabular}{|c|c|c|}
\hline ZONA ELEITORAL & Votos em 2000 & Votos em 2004 \\
\hline 1 (Centro) & 365 & 281 \\
\hline 2 (Bela Vista, Petrópolis) & 185 & 134 \\
\hline 111 (Farrapos, 4o Distrito) & 142 & 90 \\
\hline 112 (Zona Norte) & 241 & 109 \\
\hline 113 (Partenon) & 972 & 676 \\
\hline $\begin{array}{c}114 \text { (Azenha, M. Deus, } \\
\text { Cruzeiro, Teresópolis) }\end{array}$ & 1303 & 1287 \\
\hline $\begin{array}{c}158 \text { (Bom Jesus, } \\
\text { Maias, Sarandi) }\end{array}$ & 167 & 146 \\
\hline 159 (Lomba do Pinheiro) & 2187 & 641 \\
\hline 160 (Cavalhada, Tristeza) & 751 & 1181 \\
\hline 161 (Restinga) & 1332 & 6342 \\
\hline TOTAL & 7645 & \\
\hline
\end{tabular}

Tabela 2 - Votos de Valdir Caetano nas eleiçōes de 2000 e 2004, por Zona Eleitoral

\begin{tabular}{|c|c|c|}
\hline ZONA ELEITORAL & Votos em 2000 & Votos em 2004 \\
\hline 1 (Centro) & 896 & 916 \\
\hline 2 (Bela Vista, Petrópolis) & 664 & 716 \\
\hline 111 (Farrapos, 4o Distrito) & 1192 & 1112 \\
\hline 112 (Zona Norte) & 1241 & 1188 \\
\hline 113 (Partenon) & 798 & 713 \\
\hline $\begin{array}{c}114 \text { (Azenha, M. Deus, } \\
\text { Cruzeiro, Teresópolis) }\end{array}$ & 847 & 684 \\
\hline $\begin{array}{c}158 \text { (Bom Jesus, } \\
\text { Maias, Sarandi) }\end{array}$ & 3119 & 2593 \\
\hline 159 (Lomba do Pinheiro) & 1428 & 1499 \\
\hline 160 (Cavalhada, Tristeza) & 407 & 374 \\
\hline 161 (Restinga) & 321 & 343 \\
\hline TOTAL & 10913 & 10138 \\
\hline
\end{tabular}


Uma rápida análise destes números revela que, novamente, os procedimentos adotados foram bem sucedidos. A "topografia eleitoral" de Almerindo Filho demonstra uma concentração de votos em bairros do sul e do sudeste: Partenon, Azenha, MeninoDeus, Cruzeiro,Teresópolis, Restinga e parte da Lomba do Pinheiro responderam por nada menos de $78 \%$ da votação do representante do PSL. Valdir Caetano, por sua vez, obtém a maior parte de seus sufrágios entre eleitores do norte e do nordeste da cidade: Centro, Avenida Farrapos, $4^{\circ}$ Distrito, Zona Norte, Bom Jesus, Parque dos Maias e Sarandi e a outra parte da Lomba do Pinheiro perfazem aproximadamente $80 \%$ de seus votos. Outro dado que nos chama a atenção é a votação expressiva que os dois candidatosreceberam no Partenon e na Lomba do Pinheiro. Supomos que isto se deve a peculiaridades dos dois bairros: o primeiro é praticamente cortado ao meio pela avenida Ipiranga, marco que os estrategistas da Universal adotaram para dividir a cidade, enquanto a segunda é uma das regiões mais populosas de Porto Alegre, fato que pode ter levado estes mesmos sujeitos a intencionalmente dedicar partes distintas de seu território à campanha de um ou outro candidato. ${ }^{19}$

Se, por um lado, os dados nos indicam uma repetição do sucesso eleitoral destes "políticos religiosos", uma comparação dos resultados obtidos em 2000 e 2004 sugere que, além de se ver reduzido em termos globais, o número de eleitores que optaram por um dos "candidatos oficiais" da IURD decaiu em praticamente todas as regióes da cidade. Tal fato certamente suscitará reflexões por parte dos dirigentes da igreja, uma vez que estes pretendiam tomar os resultados do pleito de 2004 como indicadores capazes de determinar se lançariam ou não um terceiro candidato em 2008. Esta possibilidade se viu bastante reduzida, considerando que o próprio

\footnotetext{
${ }^{19}$ Há ainda uma outra questão que deve ser levantada, mesmo que não tenhamos à disposição dados para respondê-la: considerando que inúmeros fiéis da IURD trabalham e/ou estudam numa região da cidade e moram em outra, muitas vezes freqüentando templos diferentes conforme o dia da semana, surge um questionamento: quais serão os critérios que tais sujeitos levam em conta para definir suas escolhas eleitorais? Consideramos que apenas outras pesquisas de caráter qualitativo poderão fornecer pistas capazes de fornecer algum tipo de esclarecimento neste sentido.
}

Debates do NER, Porto Alegre, ano 5, N. 6, P. 83-112, Dezembro 2004 
Almerindo Filho ficou com a última das 12 vagas obtidas pela Frente Popular, contando, para isto, com as alterações na legislação que aumentaram para 36 a quantidade de vereadores na Câmara Municipal de Porto Alegre. Considerando que, num período de quatro anos, aumentou a quantidade de templos na cidade, o que, conseqüentemente, deve ter trazido mais fiéis para a igreja, juntamente com o fato dos vereadores contarem, agora, com uma estrutura política e institucional construída a partir de sua inserção na Câmara, recurso que não tinham no pleito de 2000, torna-se necessário encontrar explicações para este fenômeno. Sem que nos tenha sido possível explorar a questão com suficiente profundidade, pensamos que pode ser frutífero principiarmos lembrando dos comentários de Santos (2001) acerca dos resultados obtidos por Almerindo e Caetano em sua primeira eleição. $\mathrm{O}$ autor sugere que a mesma estrutura organizacional hierárquica e centralizada que garante o sucesso dos candidatos indicados pela igreja aos seus fiéis poderia ser responsável por uma limitação de suas possibilidades eleitorais. Na ocasião, este pesquisador sugeria que "o desafio posto frente à expansão eleitoral da Igreja Universal será o de expandir a audiência de seus porta-vozes para além dos eleitores mais fiéis" (Santos, 2001, p. 108). Haveria, por exemplo, uma dificuldade decorrente do fato destes sujeitos estarem, em geral, associados com partidos e discursos à direita do espectro político. A aproximação com o PT certamente trouxe nova luz sobre este quadro, mas, ainda assim, parece que a "mensagem" dos "políticos religiosos" não obteve a repercussão esperada. Ao que parece, a exposição propiciada por quatro anos de atuação parlamentar e "trabalho social" não foi suficiente para expandir as "bases eleitorais" para além do espaço da igreja.

\section{CONSIDERAÇÕES FINAIS}

Ao encerrar este trabalho, não pretendemos apresentar conclusões que se proponham definitivas. Intentamos, sim, fazer alguns apontamentos a partir do que indicou nosso material etnográfico, com a intenção de contribuir para outras pesquisas que pretendam abordar a participação de agentes

Debates do NER, Porto Alegre, ANo 5, N. 6, P. 83-112, DeZembro 2004 
religiosos nas esferas institucionais da política. Vejamos, portanto, algumas questōes que consideramos relevantes.

Primeiramente, pensamos que Renato Janine Ribeiro (2003) fornece contribuições indispensáveis para que possamos entender o caráter "nãoreligioso" da face mais pública da campanha de Valdir Caetano e Almerindo Filho. Este autor considera que a política "moderna" e "laicizada" vigente no Ocidente não dá espaço para os sentimentos e as emoções, condenando os comportam entos considerados passionais em prol das "operações da razão" (Ribeiro, 2003, p. 3). Desta maneira, não possuindo mais laços sociais suficient emente estreitos, a política se vê obrigada a recrutar agentes dotados de "novas energias" que pulsam em locais distantes das instâncias tradicionais de participação. Ganham importância, neste processo, a sociedade civil, os movimentos sociais e, naquilo que mais nos interessa nos limites deste trabalho, a religião. Entretanto, logo esta situação muda: o que era intenso e criativo se torna convencional, formalizado e incapaz de continuar atraindo as atenções da população. Desta forma, o autor chega a afirmar que a vida política é dotada de um "poder vampirizante", capaz de absorver completamente a "vitalidade" advinda de outros campos da realidade social.

Desta forma, sugerimos que esta "vampirização" à qual os dois vereadores evangélicos foram submetidos durante seus mandatos culminou numa campanha que, em grande medida, não se diferenciava daquela dos "políticos laicos”, o que era especialmente visível nos panfletos e nas aparições na televisão. Assim, estes agentes estariam se adequando às regras vigentes no campo político, o que lhes propiciaria um maior reconhecimento por parte dos agentes dominantes nesta esfera da realidade social, os chamados "profissionais da política" (Bourdieu, 1989).

Entretanto, o fato de se tornarem "secularizados" não significa que tais políticos se desvinculem de sua condição de representantes da IURD. Seu relacionamen to com as "bases elei torais" - no caso, os fiéis da igreja - combina elementos característicos da cultura política brasileira, como um padrão de relacionamentospessoais baseados na reciprocidade(Bezerra, 1999), com traços peculiares à sua condição de "can didatos oficiais" de uma insti- 
tuição religiosa, como a construção de uma imagem de "homem de Deus", em quem o voto seria, mais do que uma obrigação cívica, um "ato de fé". Evidencia-se, assim, aquela que consideramos uma de nossas principais constatações: os pastores-vereadores trabalharam, em suas campanhas, com uma divisão clara entre o que devia ser dito "dentro" e "fora" da igreja, acionando símbolos e discursos diferentes de acordo com a situação.

Por um lado, é inegável que o fato de tentarem demonstrar o quanto seu trabalho na Câmara trouxe benefícios para a população em geral indica uma pretensão de expandir as "bases" para além dos limites dos templos. Por outro, somos obrigados a questionar o sucesso dessa empreitada. No mínimo, ao percebermos que os participantes de caminhadas, carreatas e "bandeiraços" eram eminentemente os mesmos fiéis que acompanhavam as pregações dos pastores sobre a importância do voto e da escolha de candidatos "comprometidos com a palavra do Senhor", somos levados a indagar se estes eventos não estariam servindo muito mais como uma demonstração ao grande público da força das candidaturas evangélicas do que como um recurso para efetivar um proselitismo eficiente entre os não-crentes.

Em outros termos: talvez seja o momento de, novamente, nos questionarmos sobre os limites das imbricaçôes entre o religioso e o político na sociedade brasileira. Não queremos, de forma alguma, afirmar que os segmentos religiosos deixarão de cumprir um papel crucial na definição do sucesso ou fracasso de determinadas candidaturas, nem mesmo sugerir que suas lideranças deixarão de participar da política institucional. Entretanto, não podemos negar que é preciso buscar fatores além da legislação eleitoral, que reduziu as câmaras municipais da maior parte dos pequenos municípios, para explicar um declínio que, segundo o jornal O Globo (edição de 17/ 10/2004), foi bastante considerável: segundo este periódico, a IURD, neste pleito, elegeu apenas 70 vereadores em todo o país, contra os 350 das eleições anteriores. Estariam as "novas energias" advindas do campo religioso sendo definitivamen te tragadas pelo "poder vampirizan te" da política? Pensamos que esta é uma questão a ser solucionada, e somente a continuidade das pesquisas etnográficas e sociológicas poderá nos fornecer uma idéia mais precisa do que está ocorrendo. 


\section{REFERENCIAS}

BEZERRA, Marcos Otávio. Em nome das “bases”. Política, favor e dependência pessoal. Rio de Janeiro: Relume-Dumará, 1999.

BOURDIEU, Pierre. O poder simbólico. Lisboa: Difel, 1989.

CORTEN, Andre; MARY, Andre. Introduction. In: CORTEN, Andre; MARY, Andre (Org.) Imaginaires politiques et pentecôtismes, Afriquel Amérique latine. Paris: Karthala, 2000.

FRESTON, Paul. Evangelicals and Politics in Asia, Africa and Latin America. Cambridge: Cambridge University Press, 2001.

KUSCHNIR, Karina. O Cotidiano da Política. Rio de Janeiro: Jorge Zahar Editor, 2000.

MACHADO, Maria das Dores C. Igreja Universal: uma organização providência.In: ORO, Ari Pedro; CORTEN, André; DOZON, Jean-Pierre (Org.). Igreja Universal do Reino de Deus: os novos conquistadores da fé. São Paulo: Paulinas, 2003.

MARIANO, Ricardo; PIERUCCI, Antônio Flávio. O envolvimento dos pentecostais na eleição de Collor. In: PIERUCC, Antônio Flávio;PRANDI, Reginaldo. A realidade social das religiôes no Brasil. São Paulo: Hucitec, 1996.

ORO, Ari Pedro. Principes religieux et pratiques politiques des "religieux politiciens" et des "politiciens laiques" au Sud du Brésil. Trabalho apresentadona 27a Reunion Internacionale de Sociologie des Religions, Turim, Itália, 2003.

ORO, Ari Pedro. Religião e Política nas Eleições 2000 em Porto Alegre (RS). Debates do NER, ano 2, n. 3. Porto Alegre: PPGAS/UFRGS, 2001.

RIBEIRO, Renato Janine. Transcendance et immanence dans la politique et le sacré. Trabalho apresentado na $27^{\text {a }}$ Reunion Internacionale de Sociologie des Religions, Turim, Itália, 2003.

SANTOS,André Marenco. Fides Implicita: candidatosreligiosos nas eleições municipais de 2000 em Porto Alegre. Debates do NER, ano 2, n. 3. Porto Alegre: PPGAS/UFRGS, 2001. 